\title{
Rough Agave Flowers as a Potential Feed Resource for Growing Goats
}

\author{
Miguel Mellado, ${ }^{1}$ Jose E. Garcia, ${ }^{1}$ and Wolfgang Pittroff ${ }^{2}$ \\ Authors are ${ }^{1}$ Professor, Department of Animal Nutrition, University Autonoma Agraria Antonio Narro, Saltillo, Coah 25315, México; and ${ }^{2}$ Assistant \\ Professor, Department of Animal Science, University of California, Davis, CA 95616-8521, USA.
}

\begin{abstract}
The objective of this study was to evaluate the effect of different levels of rough agave (Agave scabra Ortega) flowers on dry matter intake (DMI), average daily gain (ADG), volatile fatty acid (VFA) production in the rumen, and particular serum metabolites and minerals of native $\times$ dairy growing goats (Capra hircus L.). Forty female goats with an initial weight of $11.1 \pm 1.9 \mathrm{~kg}($ mean $\pm \mathrm{SD})$ were used in a completely randomized design experiment that lasted for $84 \mathrm{~d}$. Goats were fed a completely mixed ration $(30 \%$ roughage, $70 \%$ ground corn [Zea mays L.] and soybean [Glycine max $\{\mathrm{L}$.$\} Merr] meal).$ Treatments consisted of offering goats ( 4 pens $\cdot$ group $^{-1}, 2$ goats $\cdot$ pen $^{-1}$ ) air-dry rough agave flowers, which replaced alfalfa (Medicago sativa L.) hay at 0\% (control; T0), 25\% (T25), 50\% (T50), 75\% (T75), and 100\% (T100) of the of the roughage portion of the diet. Values of nutritional parameters for rough agave flowers were in vitro organic matter digestibility, $493 \mathrm{~g} \cdot \mathrm{kg}^{-1}$; crude protein, $115 \mathrm{~g} \cdot \mathrm{kg}^{-1}$; and metabolizable energy, $6.29 \mathrm{MJ} \cdot \mathrm{kg}^{-1} \mathrm{DMI}$. There were differences $(P<0.05)$ in ADG (range, $\left.108-155 \mathrm{~g} \cdot \mathrm{d}^{-1}\right)$ between diets. Goats fed T0 had higher $(P<0.05)$ gains than goats fed T50 and T100. DMI was not affected by dietary treatments (range, $3.4 \%$ to $3.6 \%$ of body weight). Feed conversion ratio (FCR, defined as DMI/ADG) increased $(P<0.05) 27 \%$ with total substitution of alfalfa by rough agave flowers, in comparison with T0. Lower $(P<0.05)$ values of total VFA were obtained with T100, in comparison with all other dietary treatments. These results demonstrated that totally replacing alfalfa with rough agave flowers in diets did not affect DMI but decreased AGD and compromised FCR. Thus, rough agave flowers have the potential to partially replace alfalfa in diets for growing goats.
\end{abstract}

\section{Resumen}

El objetivo de este estudio fue evaluar el efecto de diferentes niveles de flores de maguey cenizo (Agave scabra Ortega) sobre el consumo de alimento (CA), ganancia diaria de peso (GDP), producción de ácidos grasos volátiles (AGV) en el rumen y algunos metabolitos y minerales de la sangre en cabras nativas $\times$ lecheras en crecimiento. Se utilizaron cuarenta cabras con un peso inicial de $11.1 \mathrm{~kg} \pm 1.9$ (media $\pm \mathrm{DE}$ ) en un diseño completamente al azar con cuatro corrales $\left(2 \mathrm{cabras} \cdot \mathrm{corral}^{-1}\right)$ por grupo. La prueba de alimentación duró 84 días. Los tratamientos consistieron en el reemplazo de alfalfa por 0\% (testigo; T0), 25\% (T25), 50\% (T50), 75\% (T75), y 100\% (T100) por flores de maguey cenizo, en una dieta basada en grano de maíz y harina de soya. Las cabras se alimentaban dos veces por día con una ración completa donde el forraje constituía 30\% de la dieta. Los parámetros nutricionales de flores de maguey cenizo fueron: digestibilidad de la materia orgánica, $493 \mathrm{~g} \cdot \mathrm{kg}^{-1} ; \mathrm{proteína} \mathrm{cruda,}$ $115 \mathrm{~g} \cdot \mathrm{kg}^{-1}$; y energía metabolizable, $6.29 \mathrm{MJ} \cdot \mathrm{kg}^{-1} \mathrm{MS}$. Se detectaron diferencias $(P<0.05)$ en la GDP (rango entre 108 y $155 \mathrm{~g} \cdot \mathrm{d}^{-1}$ ). El CA no fue afectado por los niveles de flores de maguey cenizo (rango de 3.4\% a 3.6\% del peso vivo). La relación CA/GDP se incrementó $(P<0.05) 27 \%$ con la sustitución total de alfalfa por flores de maguey cenizo, con relación a T0. Menores valores $(P<0.05)$ de AGV se obtuvieron en T100, en comparación con las otras dietas. El reemplazo total de alfalfa por flores de maguey cenizo disminuyó $(P<0.01)$ la proporción de propionato e incrementó la proporción de acetato en el rumen, comparado con T0. Estos resultados demostraron que el reemplazo total de alfalfa por flores de maguey cenizo no afectó el CA, disminuyó ligeramente la GDP, pero afectó negativamente la relación CA/GDP. Entonces, las flores del maguey cenizo tienen el potencial de reemplazar parcialmente la alfalfa en dietas para cabras en confinamiento.

Key Words: blood metabolites, digestibility, feed conversion, feed intake, rough agave, volatile fatty acids

\section{INTRODUCTION}

Production of alfalfa (Medicago sativa L.) remains a top priority of most intensive dairy cattle (Bos taurus L.) and goat (Capra hircus L.) operations in the arid zones of northern

Research was funded by The University of California Institute for Mexico and the United States (UC MEXUS) and by Consejo Nacional de Ciencia y Technología (CONACYT, Mexico).

The mention of a proprietary product does not constitute a guarantee or warranty of the product by the authors and does not imply its approval to the exclusion of the other products that also may be suitable.

Correspondence: Miguel Mellado, University Autonoma Agraria Antonio Narro, Dept of Animal Nutrition, Saltillo, Coah 25315, Mexico. Email: mmellbosq@yahoo.com

Manuscript received 30 July 2007; manuscript accepted 19 August 2008.
Mexico, but yield trends have stagnated over the past years because of an increasing water deficit in areas with $<250 \mathrm{~mm}$ of annual rainfall. Water tables are falling because of heavy use of subsurface water for irrigated agriculture (Comisión Nacional del Agua 2002). Recent studies predict decreases in precipitation for northern Mexico even under the most optimistic scenarios (Weiss and Overpeck 2005). Thus, contrary to previous expectations, reduction of available water in the arid zones of the southwestern United States (Li et al. 2005 ) and Mexico (García-Salazar 2006) is likely to become a critical constraint much earlier than anticipated. Accordingly, it is now a priority to develop management alternatives for feeding that minimize dependence upon irrigation for intensive ruminant production systems. Thus, environmental concerns 
mandate a lower dependence on alfalfa in desert areas. Possible substitutes for alfalfa in this arid environment are different desert plants with high forage potential, such as rough agave (Agave scabra Ortega). This plant is highly efficient in the use of water and can withstand extended drought periods. For centuries, rough agave has been harvested to feed livestock in northern Mexico. Recently, this plant has also been used to build retaining walls for preventing soil erosion and to construct live barriers or hedges on large expanses of arid landscapes, through federally funded government programs. Thus, this succulent plant provides abundant forage in many rangelands of northern Mexico.

The foliage of this plant contains low levels of protein and high levels of cell wall contents (Martinez 1994), which limit its use as animal fodder. Even so, deer and cattle readily eat the flower stalks of this Agavaceae species. To date, animal production trials to assess the nutritional quality of flowers of rough agave flowers have not been conducted. Therefore, the objectives of this experiment were 1) to determine the chemical composition of dried rough agave flowers, and 2) to evaluate how goats respond to increasing levels of rough agave flowers in the ration, in terms of feed intake, weight gain, and ruminal fermentation patterns.

\section{MATERIAL AND METHODS}

\section{Goat Management}

The experiment was conducted at the University Autonoma Agraria Antonio Narro (lat $25^{\circ} 22^{\prime} \mathrm{N}$, long $101^{\circ} 00^{\prime} \mathrm{W}$ ). Forty 2 -mo-old crossbred (native $\times$ European dairy goats) female growing goats, with an average initial body weight of $11.1 \pm 1.9 \mathrm{~kg}$ (mean $\pm \mathrm{SD})$ were randomly allotted to five dietary groups. Before early weaning, kids grazed with their mothers on rangeland pasture typical of the Chihuahuan desert ecoregion, where they were exposed to different members of the Agavaceae family, although they did not consume rough agave flowers before the commencement of the confinement trial. Eight goats were used per treatment, with 2 goats $\cdot$ pen $^{-1}$; thus, the experimental units were the pens $(n=4)$.

Before the initiation of the study, goats were vaccinated against several strains of clostridia and treated for elimination of internal and external parasites with Ivomec (Merck and Company, Rahway, NJ). Goats were housed in open sheds, with free access to water and feed (experimental diets) throughout the 10-d adaptation period, which was followed immediately by the 84-d study period. Goats were weighed at the beginning of the trial and every $2 \mathrm{wk}$ thereafter.

Throughout the experiment, the animals were offered a total mixed ration (salt and buffer included) formulated to meet the requirements for maximum daily gains of growing goats $\left(150 \mathrm{~g} \cdot \mathrm{d}^{-1}, 0.92 \mathrm{Mcal}\right.$ net energy gain, $45 \mathrm{~g}$ digestible protein; National Research Council 2007). The roughage component of the diet $(30 \%)$ was alfalfa, which was replaced by dried flowers of rough agave as specified in the treatment definitions (Table 1).

\section{Collection of Rough Agave Flowers}

Rough agave flowers (panicles of blossoms including the branching stems) were collected at full bloom (no ripe seeds
Table 1. Ingredient composition (percentage of dry matter) of diets containing $0 \%$ (control), 25\%,50\%, 75\%, and 100\% rough agave flowers as the roughage contained in the diet.

\begin{tabular}{lrrrrr}
\hline \multicolumn{1}{c}{ Ingredient } & T0 & T25 & T50 & T75 & T100 $^{1}$ \\
\hline Alfalfa hay & 30.0 & 22.5 & 15.0 & 7.5 & 0.0 \\
Rough agave & 0.0 & 7.5 & 15.0 & 22.5 & 30.0 \\
Corn grain & 49.9 & 49.7 & 49.6 & 49.4 & 49.2 \\
Soybean meal & 6.3 & 6.5 & 6.7 & 6.9 & 7.1 \\
Animal fat & 0.5 & 0.5 & 0.5 & 0.5 & 0.5 \\
Cane molasses & 10.0 & 10.0 & 10.0 & 10.0 & 10.0 \\
Bicarbonate & 0.5 & 0.5 & 0.5 & 0.5 & 0.5 \\
Mineral mix & 2.5 & 2.5 & 2.5 & 2.5 & 2.5 \\
Sodium chloride & 0.25 & 0.25 & 0.25 & 0.25 & 0.25 \\
\hline
\end{tabular}

${ }^{1}$ T0 to T100 indicates air-dried rough agave flowers at $0 \%$ (control), $25 \%, 50 \%, 75 \%$, and $100 \%$ of the roughage contained in the diet.

${ }^{2}$ Macro and micro elements, monensin, and vitamins A, D, and E (GANATEC-25; Técnicas Nutricionales S. A. de C. V., San Nicolas de los Garza, Mexico).

present) in the range adjacent to the study site by handclipping. A ladder was used to reach the flowers, and approximately $115 \mathrm{~kg}$ of this roughage (dry matter [DM]) was collected by a person each day.

Rough agave flowers were dried in the sun to a constant humidity and passed through a forage chopper fitted with a 5$\mathrm{mm}$ screen to reduce the staple length of the forage to minimize selection by goats. The ground material was then mixed with the other ingredients of the diet. Alfalfa hay ( $25 \%$ bloom) was obtained from a commercial source and ground in a similar manner, then mixed with the other dietary ingredients. The concentrate component of the diet $(70 \%)$ consisted of ground corn grain corn (Zea mays L.) and soybean (Glycine max [L.] Merr) meal.

\section{Feeding Trial Protocol}

Animals were fed at 0900 and 1800 hours, with roughly half of the daily allocation given at each feeding. Samples of the total mixed diet and refusals from each pen were collected daily, bulked, and dried at $105^{\circ} \mathrm{C}$ for $24 \mathrm{~h}$ to determine dry matter intake (DMI). All rations were offered ad libitum in amounts sufficient to allow at least a $15 \%$ refusal.

Average daily gain (ADG), DMI (manual recording of what was eaten by 2 goats $\cdot$ pen $^{-1}$ ), and feed conversion ratio (FCR, defined as DMI/ADG) were determined for all goats on a pen basis.

\section{Chemical Analysis and In Vitro Gas Production}

Three rough agave flowers (panicles including the branching stems) were randomly selected from representative areas of the range to estimate forage quality. Three samples of alfalfa hay were also used for assessing chemical composition. These samples were ground in a Wiley mill to pass through a 2-mm screen. Chemical analyses of ground samples were conducted in duplicate. Ash was determined by ignition of dried samples in a muffle furnace at $550^{\circ} \mathrm{C}$ for $3 \mathrm{~h}$ (Association of Official Analytical Chemists [AOAC] 1990; method 942.05). The crude protein $(\mathrm{CP})$ was determined by a Kjeldahl method (AOAC 1990; method 954.01). Neutral detergent fiber (NDF) and acid detergent fiber (ADF) were determined using methods 
described by Van Soest et al. (1991). Soluble or free-bound condensed tannins in the forage samples were extracted using sodium dodecyl sulfate and 2- $\beta$-mercaptoethanol solution (Terrill et al. 1992). Gas production was determined as described by Menke and Steingass (1988).

A 200-mg amount of each ground sample was weighed and placed in $100-\mathrm{mL}$, calibrated glass syringes in an anaerobic medium, with pistons lubricated with petroleum jelly. A sodium and ammonium carbonate buffer $\left(35 \mathrm{~g} \mathrm{NaHCO}_{3}\right.$ plus $\left.4 \mathrm{~g} \mathrm{NH}_{4} \mathrm{HCO}_{3} \cdot \mathrm{L}\right)$, in a ratio $1: 2(\mathrm{v} / \mathrm{v})$, was prepared and placed in a water bath at $39^{\circ} \mathrm{C}$ under a carbon dioxide atmosphere. Rumen fluid was collected after the morning feeding from two ruminally fistulated, nonlactating Holstein cows fed a diet of mostly oat (Avena sativa L.) hay with a small amount of alfalfa hay $\left(12 \% \mathrm{CP}, 2.40 \mathrm{Mcal} \mathrm{kg}^{-1}\right.$ metabolized energy $[\mathrm{ME}], \mathrm{DM})$. The fluid was placed into prewarmed thermos flasks, then mixed, filtered, and flushed with carbon dioxide in the laboratory.

About $30 \mathrm{~mL}$ of buffered rumen fluid was dispensed into syringes containing the forages. After closing the clips on the silicon tube at the syringe tip, syringes were gently shaken and tubes were opened to remove gas by pushing the piston upwards to achieve complete removal of gas. The clip was closed, this initial volume recorded, and syringes were placed in a water bath at $39^{\circ} \mathrm{C}$. Volume of gas produced was recorded every $4 \mathrm{~h}$ from 0 to 72 hours after incubation (incubation terminated after recording the $72 \mathrm{~h}$ gas volume). Volume of gas $\left(\mathrm{mL} \cdot \mathrm{g}^{-1} \mathrm{DM}\right)$ produced after $24 \mathrm{~h}$ of incubation (GV24) was used as an index of digestibility and energy feed value, as suggested by Menke and Steingass (1988).

Organic matter digestibility (OMD; $\left.\mathrm{g} \cdot \mathrm{kg}^{-1} \mathrm{DM}\right)$ and $\mathrm{ME}$ content was calculated by the following relationships:

$$
\begin{aligned}
\mathrm{OMD}= & 14.88+(0.889 \cdot \mathrm{GV} 24)+(0.45 \cdot \mathrm{CP}) \\
& +(0.0651 \cdot \mathrm{XA})
\end{aligned}
$$

$$
\begin{aligned}
\mathrm{ME}\left(\mathrm{MJ} \cdot \mathrm{kg}^{-1} \mathrm{DM}\right)= & 2.2+(0.136 \cdot \mathrm{GV} 24) \\
& +(0.057 \cdot \mathrm{CP})+\left(0.0029 \cdot \mathrm{CP}^{2}\right)
\end{aligned}
$$

where XA denotes ash in grams per kilogram DM, CP denotes crude protein in grams per kilogram DM, and GV24 denotes cumulative gas production in milliliters at $24 \mathrm{~h}$ of incubation.

Rate and extent of gas production were determined by fitting gas production data to the nonlinear equation of Brody:

$$
\text { GAS }=\text { GAST } \times\left(1-\left[b \cdot e^{-c^{\cdot} t}\right]\right)
$$

where GAS $(\mathrm{mL})$ denotes the cumulative gas production at time $t$, GAST is the asymptotic gas production, $c(\mathrm{~mL}$. $\mathrm{h}^{-1}$ ) is the rate of gas accumulation, and $b$ is the scale parameter.

\section{Rumen and Blood Parameters}

At the end of the feeding trial (day 85 of the study period), ruminal fluid (approximately $50 \mathrm{~mL}$ ) was collected from all goats with a stomach tube connected to an electric vacuum pump at $0 \mathrm{~h}, 2 \mathrm{~h}$, and $4 \mathrm{~h}$ postfeeding. Samples were strained through four layers of cheesecloth. A $16-\mathrm{mL}$ subsample $\cdot$ goat $^{-1}$ was acidified by addition of $4 \mathrm{~mL}$ of $24 \%(\mathrm{wt} / \mathrm{vol})$ metaphosphoric acid and stored $\left(-20^{\circ} \mathrm{C}\right)$ for later processing and analyses. Volatile fatty acid (VFA) determinations were by the method described by Keeney (1955).

On the final day of the experiment, blood was collected from the jugular vein of all goats before feeding. The blood sample was allowed to coagulate and, after centrifugation at $2400 \times \mathrm{g}$ for $20 \mathrm{~min}$, the serum was decanted and stored at $-20^{\circ} \mathrm{C}$ until analyzed for metabolites and microminerals.

Serum metabolites were determined using spectrophotometric methods. Serum total protein concentration was determined with a kit based on the bicinchoninic acid reagent with bovine serum albumin as a protein standard (Pierce Chemical, Rockford, IL). Glucose was assayed with kit 115-A based on glucose oxidase, and urea was quantified using kit 640-A based on urease (Sigma-Aldrich Co., St. Louis, MO). Creatinine was measured in serum using the QuantiChromTM Creatinine Assay Kit (DICT-500; BioAssay Systems, Hayward, CA). Albumin was determined with the albumin fluorescence assay kit (Sigma-Aldrich Co., St. Louis, MO). Serum cholesterol was determined using the EnzyChromTM cholesterol assay kit (ECCH-100; BioAssay Systems, Hayward, CA). Serum microminerals (magnesium $[\mathrm{Mg}]$, copper $[\mathrm{Cu}]$, and zinc $[\mathrm{Zn}]$ ) were determined by atomic absorption spectrophotometry (Perkin Elmer Instruments model 2380).

\section{Statistical Analysis}

Forage composition data were analyzed statistically using Student's paired $t$ test (SAS 1990), using the $P<0.05$ level as significant.

Performance data were analyzed statistically by analysis of variance (PROC GLM, SAS 1990). In the growth trial, DMI, ADG, and FCR were calculated on a per-pen basis and were adjusted using initial body weight as a covariate in the model. Residual mean square was the error term, and a pen with two animals was considered the experimental unit. When differences were significant, the Tukey's test was used to compare treatment means. Treatment effects on levels of minerals and concentrations of particular serum metabolites were examined by analysis of variance (PROC GLM, SAS 1990). For ruminal VFA, effects that resulted from treatment, time, and treatment $\times$ time interactions were analyzed as repeated measures in time using the mixed-model procedure (PROC MIXED) of SAS (1990). Residual mean square was the error term. A level of $P<0.05$ was chosen as the minimum for statistical significance.

\section{RESULTS AND DISCUSSION}

\section{Nutritional Composition}

$\mathrm{CP}$ content of rough agave flowers was much lower $(P<0.01)$ than those of alfalfa hay (Table 2); it was comparable to that of leaves of most desert fodder shrubs of northern Mexico (Ramirez and Hernandez 1997; Ramírez-Orduña et al. 2003). Rough agave flowers contained higher $(P<0.01)$ fiber (NDF and ADF) than alfalfa. Both NDF and ADF values of rough 
Table 2. Chemical composition $\left(\mathrm{g} \cdot \mathrm{kg}^{-1}\right.$ of dry matter; mean $\left.\pm \mathrm{SD}\right)$ of rough agave flowers collected by hand-clipping on Chihuahuan native range in northern Mexico, and alfalfa hay. ${ }^{1}$

\begin{tabular}{lcc}
\hline \multicolumn{1}{c}{ Item } & Rough agave flowers & Alfalfa hay \\
\hline Dry matter & $865 \pm 7.2 \mathrm{a}$ & $801 \pm 6.1 \mathrm{~b}$ \\
Ash & $98 \pm 3.6 \mathrm{a}$ & $80 \pm 3.1 \mathrm{~b}$ \\
Crude fat & $21 \pm 2.0 \mathrm{a}$ & $33 \pm 1.9 \mathrm{~b}$ \\
Crude protein & $115 \pm 3.5 \mathrm{a}$ & $170 \pm 4.1 \mathrm{~b}$ \\
Crude fiber & $266 \pm 7.5 \mathrm{a}$ & $231 \pm 5.5 \mathrm{~b}$ \\
Nitrogen free extract & $500 \pm 8.7 \mathrm{a}$ & $486 \pm 5.3 \mathrm{a}$ \\
Neutral detergent fiber & $612 \pm 9.5 \mathrm{a}$ & $597 \pm 7.6 \mathrm{a}$ \\
Acid detergent fiber & $493 \pm 4.9 \mathrm{a}$ & $463 \pm 6.0 \mathrm{~b}$ \\
\hline
\end{tabular}

${ }^{1}$ Means with different lowercase letters, within a row, differ at $P<0.01$.

agave flowers are higher than that reported for other succulent fodder shrubs (Sirohi et al. 1997; Misra et al. 2006). Ash content of rough agave flowers was higher $(P<0.01)$ than that of alfalfa hay, whereas crude fat was $37 \%$ higher $(P<0.01)$ in alfalfa hay compared with rough agave flowers. Nitrogen-free (N-free) extract was similar in both agave flowers and alfalfa. Tannins were not detected in rough agave flowers.

The ME values for rough agave flowers were lower than that of alfalfa (Table 3) and those of high-quality Gramineae; in fact, its energy content was nearly half of that reported for high-energy grasses (Givens et al. 1992; Moss et al. 1992). Thus, it is suggested that rough agave can be used only as a basic forage in the diet of growing goats, but not as a highenergy feed. The low-energy concentration of rough agave flowers was reflected in a moderated $\mathrm{N}$-free extract content (Table 2), which is indicative of a low concentration of soluble carbohydrates.

OMD of rough agave flowers was not high (Table 3), as has been reported for foliage of other Agavaceae family members (Yerena et al. 1977; Martinez 1994). The large differences in digestibility among rough agave and alfalfa may be partly attributed to the ample variations in chemical composition (mainly higher cell wall content and lower CP in rough agave) in these forages. In particular, fiber fractions appear to be one of the main constraints to DM degradation of forages in the rumen (Getachew et al. 2004).

Total gas accumulation was much higher for alfalfa hay compared with rough agave flowers (Table 3). However, values for the GAST of rough agave flowers are higher than values reported by Cerrillo et al. (2006) for forages (except rough agave flowers) consumed by grazing goats in the same type of vegetation.

The potential GAST is associated with degradability of feed (Khazaal et al. 1995). As expected, in the current study, the cumulative gas production was highest with the forage containing the lower fiber fraction (alfalfa) and was lowest with rough agave flowers (highest fiber fraction).

\section{Feeding Trial}

Goats achieved average daily gains $>106 \mathrm{~g} \cdot \mathrm{d}^{-1}$ with the highest level of rough agave flowers in the diet, with no differences between T0, T25, and T75, but goats offered T50 and T100 grew slower $(P<0.05)$ compared with goats receiving other experimental diets (Table 4). We do not have
Table 3. Parameters estimated from in vitro gas production recorded every $4 \mathrm{~h}$ from $0 \mathrm{~h}$ to $72 \mathrm{~h}$ for rough agave flowers and alfalfa hay.

\begin{tabular}{lcc}
\hline \multicolumn{1}{c}{ Item $^{1}$} & Rough agave flowers & Alfalfa \\
\hline Potential gas production $\left(\mathrm{mL} \cdot \mathrm{g}^{-1} \mathrm{DM}\right)$ & 0.93 & 1.60 \\
Rate gas accumulation $\left(\mathrm{mL} \cdot \mathrm{h}^{-1}\right)$ & 0.13 & 0.11 \\
Total gas production $\left(\mathrm{mL} \cdot \mathrm{g}^{-1} \mathrm{DM}\right)$ & 133 & 223 \\
In vitro organic matter digestibility $\left(\mathrm{g} \cdot \mathrm{kg}^{-1}\right)$ & 493 & 637 \\
Metabolizable energy $\left(\mathrm{MJ} \cdot \mathrm{kg}^{-1} \mathrm{DM}\right)$ & 6.29 & 9.72 \\
\hline
\end{tabular}

${ }^{1} \mathrm{DM}$ indicates dry matter.

an explanation for the observed differences in daily gains between T25 and T50. These results indicate that forage quality of flowers of rough agave did not match goat nutritional requirements for maximum growth rate $\left(150 \mathrm{~g} \cdot \mathrm{d}^{-1}\right)$. Low concentrations of protein in feed depress digestibility of DM and other nutrient fractions (Hill et al. 1986), and this may have been one of the factors influencing slower growth rate in goats receiving T100. The NDF content in rough agave flowers was higher than $600 \mathrm{~g} \cdot \mathrm{kg}^{-1} \mathrm{DM}$, which is considered safe for acceptable intakes of forage (Meissner 1997). However, the high content of structural carbohydrates in T100 did not reduce DMI, but possibly, it affected OMD because indigestible fiber increased exponentially with NDF (Gustavsson and Martinsson 2004).

DMI did not decrease $(P>0.05)$ with increasing inclusion of rough agave flowers. DMI ranged from $3.4 \%$ to $3.6 \%$ body weight (Table 4), which is within the range reported for goats fed high-energy diets (Richards et al. 1994) or by-productbased diets (Lallo 1996; Abebe et al. 2005). Thus, palatability did not appear to be a limiting factor for ingestion of this roughage. Lack of rough agave flowers effects on DMI is similar to other results observed with fodder tree species replacing alfalfa (Azócar et al. 1996; Nantoumé et al. 2001; McMillan et al. 2002) in goat diets.

FCR was lower $(P<0.05)$ in goats fed T0 and T25 diets than those fed T50 and T100 (Table 4). FCR increased 27\% with total substitution of alfalfa by rough agave flowers, in comparison to the control diet. Lower FCR observed with T25 was possibly the result of a positive associative effect upon available energy concentration of the total diet because the addition of alfalfa to nonlegume forages stimulates digestibility of the basal feed as well as increasing the digestibility of the total feed (Hunt et al. 1985; Grigsby et al. 1991). In our study, the control diet was adequate in nitrogen $(\mathrm{N})$ concentration and energy, but rough agave flowers would be expected to provide suboptimal rumen $\mathrm{N}$ and ME. Therefore, the reduction in FCR observed with the highest levels of rough agave flowers in the diet may have been due to both a lower supply of dietary energy and decreased $\mathrm{N}$ digestion and use. FCR tends to improve with increasing nutritional quality of the diet (Negesse et al. 2001) because higher CP intake usually improves concentration of rumen ammonia-nitrogen $\left(\mathrm{NH}_{3}-\right.$ $\mathrm{N})$, which promotes cellulolytic microorganisms to effectively ferment plant fiber (Ørskov 1982). Despite the low FCR value in T100, this value is close to those found in other feeding studies with goats offered high-energy feedlot diets (Sheridan et al. 2003; Aregheore 2006). 
Table 4. Performance data for mixed-breed growing goats fed different levels of rough agave flowers for $84 \mathrm{~d}$. Values are means \pm SD. ${ }^{1,2}$

\begin{tabular}{|c|c|c|c|c|c|}
\hline Item $^{3}$ & T0 & T25 & T50 & $\mathrm{T} 75$ & $\mathrm{~T} 100^{1}$ \\
\hline Initial live weight, $\mathrm{kg}$ & $11.1 \pm 1.9$ & $11.4 \pm 2.8$ & $10.5 \pm 1.7$ & $10.9 \pm 1.0$ & $11.8 \pm 2.3$ \\
\hline Final live weight, kg & $22.3 \pm 2.6$ & $24.4 \pm 3.4$ & $19.4 \pm 2.1$ & $21.4 \pm 2.7$ & $20.8 \pm 3.8$ \\
\hline Average daily gain, $\mathrm{g}$ & $132 \pm 32 \mathrm{a}$ & $155 \pm 22 \mathrm{a}$ & $106 \pm 9 b$ & $125 \pm 27 a b$ & $108 \pm 23 b$ \\
\hline Daily DMI, g & $578 \pm 64 a$ & $605 \pm 54 a$ & $530 \pm 62 \mathrm{a}$ & $586 \pm 38 a$ & $583 \pm 36 a$ \\
\hline Daily DMI, \% BW & 3.5 & 3.4 & 3.5 & 3.6 & 3.6 \\
\hline FCR (DMI/ADG), g/g & $4.5 \pm 0.7 \mathrm{ab}$ & $4.0 \pm 0.7 \mathrm{a}$ & $4.9 \pm 0.3 b c$ & $4.8 \pm 0.7 b c$ & $5.6 \pm 0.9 c$ \\
\hline
\end{tabular}

${ }^{1} \mathrm{~T} 0$ to $\mathrm{T} 100$ indicates air-dried rough agave flowers at $0 \%$ (control), $25 \%, 50 \%, 75 \%$, and $100 \%$ of the roughage contained in the diet.

${ }^{2}$ Means within the same row without a common lowercase letter differ at $P<0.05$.

${ }^{3} \mathrm{DMI}$ indicates dry matter intake at Daily DMI = ([initial live weight + final liveweight]/2); BW, body weight; ADG, average daily gain; and FCR, feed conversion ratio.

\section{VFA and Blood Parameters}

A time $\times$ level of rough agave flowers interaction $(P<0.05)$ was observed for ruminal total VFA; therefore the data were analyzed for effect of diets within times post-feeding. At $0 \mathrm{~h}$, $2 \mathrm{~h}$, and $4 \mathrm{~h}$ postfeeding, ruminal concentrations of VFA in goats receiving T0 were respectively $19 \%, 4 \%$, and $28 \%$ greater $(P<0.01)$ than goats on T100 (Table 5), reflecting a reduced microbial activity with the highest level of rough agave flowers. In vitro studies indicate that, in general, browse forage from trees and shrubs growing in the Chihuahuan desert range produce lower total VFA values than alfalfa hay (Holechek et al. 1989; Ramirez et al. 1997). In vivo studies have also shown a positive associative effect of supplementing barley (Hordeum vulgare L.) straw-based diets with alfalfa in terms of higher rumen VFA concentration (Haddad 2000). Diet $\times$ time of day interaction was not observed for molar proportion of acetate. Both time postfeeding and levels of rough agave flowers affected molar proportion of this VFA, being five percentage points higher $(P<0.01)$ with T100 than with T0 (Table 5).

Molar proportion of propionate was also affected by time postfeeding and levels of rough agave flowers $(P<0.05)$, but not by the interaction diet $\times$ time, decreasing this VFA as levels of rough agave flowers increased. The increase in propionate seemed to be at the expense of acetate. The increases in propionate production with the highest levels of alfalfa indicate that the changes were primarily functions of fermentation of carbohydrates provided by this legume. Increasing levels of rough agave flowers tended to decrease $(P=0.08)$ molar proportion of butyrate, whereas the acetate:propionate ratio was positively related to increasing levels of rough agave flowers (Table 5). These data show that the slower growth rate

Table 5. Total concentration and proportion of volatile fatty acids in rumen fluid of goats fed for $84 \mathrm{~d}$ different levels of rough agave flowers. ${ }^{1}$

\begin{tabular}{lrrrrrr}
\hline \multicolumn{1}{c}{ Volatile fatty acids ${ }^{2}$} & T0 & T25 & T50 & T75 & T100 & SE $^{3}$ \\
\hline${ }^{4}$ Total concentration, mM & 94.7 & 90.3 & 99.7 & 84.3 & 81.0 & 5.6 \\
${ }^{4}$ Acetate, mol $\cdot 100 \mathrm{~mol}^{-1}$ & 59.8 & 60.0 & 61.9 & 64.4 & 64.5 & 1.3 \\
${ }^{4}$ Propionate, mol $\cdot 100 \mathrm{~mol}^{-1}$ & 25.3 & 27.2 & 23.8 & 22.7 & 21.3 & 1.4 \\
${ }^{5}$ Butirate, mol $\cdot 100 \mathrm{~mol}^{-1}$ & 15.0 & 12.8 & 14.3 & 12.8 & 13.9 & 1.0 \\
${ }^{5}$ Acetate:propionate ratio & 2.4 & 2.2 & 2.6 & 2.8 & 3.0 & 0.3 \\
\hline${ }^{1}$ T0 to T100 indicates air-dried rough agave flowers at $0 \%$ (control), $25 \%, 50 \%, 75 \%$, and \\
$100 \%$ of the roughage contained in the diet. \\
${ }^{2}$ Mean of 0 h, 2 h, and 4 h postfeeding observations. \\
${ }^{3}$ Common standard error of treatment means. \\
${ }^{4}$ Differences between T0 vs. T75 and T100 at $P<0.05$. \\
${ }^{5}$ Rough agave flowers level effect at $P=0.08$.
\end{tabular}

of goats on T50 and T100 diets can be explained by basic rumen fermentation patterns, along with lower protein levels in diets with the highest percentages of rough agave flowers.

Serum glucose, creatinine, albumin, total proteins, and $\mathrm{Mg}$, $\mathrm{Cu}$, and $\mathrm{Zn}$ did not differ among dietary treatments $(P>0.05)$. Concentrations of serum urea were higher $(P<0.01)$ in T0, T25, and T50 than in T75 and T100 (Table 6). Urea nitrogen in blood is a good indicator of concentration of rumen ammonia, which in turn is closely related to intake and solubility of the nitrogen-containing compounds contained in the diet (Magdus et al. 1988; Carlsson and Pehrson 1994). In the present trial, the total replacement of alfalfa by rough agave flowers apparently affected energy and protein use by goats, although this reduction in nitrogen use by goats on T100 apparently was not severe enough to provoke a turnover of the protein pool in the body because creatinine concentrations were unchanged $(P>0.05)$ by dietary treatments (Table 6). This apparent reduction in nutrient use by goats could have been the result of the inability of the rumen microflora to break down the rough agave.

Blood cholesterol was also sensitive to diets, with goats consuming the T25 diet having the highest $(P<0.01)$ serum cholesterol concentrations compared with goats consuming all other diets (Table 6). The high growth rate of goats on the T25 diet may explain this response because blood cholesterol concentration is positively associated with body condition scores in goats (Cabiddu et al. 1999).

\section{MANAGEMENT IMPLICATIONS}

The present study demonstrated the viability of using rough agave flowers in feedlot diets for goats because replacing $75 \%$ of the alfalfa with this forage did not affect ADG, DMI, and ruminal fermentation characteristics. Rough agave flowers do have agronomic characteristics that make them suitable as dryland forage production and as a possible substitute for alfalfa. Thus, in arid zones, this available, drought-resistant, nontoxic, and accessible forage would be ecologically desirable to use as a replacement for alfalfa.

The impact of using rough agave flowers as roughage for goats on the stability of the rough agave population is unknown. It is expected that, with sustainable harvest practices, the rough agave population would not be disturbed, because this plant leaves young offsets, after the plant flowers and dies. However, it would be necessary to determine the impact of eliminating the flowers of rough agave on the floral 
Table 6. Serum metabolites and minerals for mixed-breed goats fed different levels of rough agave flowers for $84 \mathrm{~d}$. Values are means \pm SD. ${ }^{1,2}$

\begin{tabular}{|c|c|c|c|c|c|}
\hline Parameters & T0 & T25 & T50 & T75 & T100 \\
\hline Glucose $\left(\mathrm{mg} \cdot \mathrm{dL}^{-1}\right)$ & $64.1 \pm 8.6 \mathrm{a}$ & $67.1 \pm 9.8 \mathrm{a}$ & $69.4 \pm 9.9 a$ & $67.0 \pm 9.3 a$ & $66.2 \pm 11.6 \mathrm{a}$ \\
\hline Urea $\mathrm{N}\left(\mathrm{mg} \cdot \mathrm{dL}^{-1}\right)$ & $22.6 \pm 3.7 \mathrm{a}$ & $20.3 \pm 2.2 a b$ & $22.4 \pm 4.7 \mathrm{ab}$ & $20.1 \pm 2.2 b$ & $20.1 \pm 1.1 b$ \\
\hline Creatinine $\left(\mathrm{mg} \cdot \mathrm{dL}^{-1}\right)$ & $1.6 \pm 0.7 \mathrm{a}$ & $1.7 \pm 0.6 \mathrm{a}$ & $1.7 \pm 0.7 \mathrm{a}$ & $1.7 \pm 0.7 \mathrm{a}$ & $1.8 \pm 0.7 \mathrm{a}$ \\
\hline Total proteins $\left(\mathrm{mg} \cdot \mathrm{dL}^{-1}\right)$ & $6.8 \pm 0.9 \mathrm{a}$ & $7.1 \pm 0.6 \mathrm{a}$ & $6.8 \pm 1.0 \mathrm{a}$ & $6.7 \pm 1.0 \mathrm{a}$ & $6.9 \pm 0.7 \mathrm{a}$ \\
\hline Albumin $\left(\mathrm{mg} \cdot \mathrm{dL}^{-1}\right)$ & $3.6 \pm 0.7 \mathrm{a}$ & $3.4 \pm 0.5 \mathrm{a}$ & $3.7 \pm 0.8 \mathrm{a}$ & $3.4 \pm 0.8 \mathrm{a}$ & $3.3 \pm 0.5 \mathrm{a}$ \\
\hline Cholesterol $\left(\mathrm{mg} \cdot \mathrm{dL}^{-1}\right)$ & $79 \pm 12 b$ & $91 \pm 22 \mathrm{a}$ & $78 \pm 19 b$ & $77 \pm 17 b$ & $86 \pm 23 a b$ \\
\hline Magnesium $\left(\mathrm{mg} \cdot \mathrm{dL}^{-1}\right)$ & $1.9 \pm 0.4 \mathrm{a}$ & $2.1 \pm 0.6 \mathrm{a}$ & $2.0 \pm 0.5 \mathrm{a}$ & $2.0 \pm 0.5 \mathrm{a}$ & $1.9 \pm 0.4 \mathrm{a}$ \\
\hline Copper $\left(\mathrm{mg} \cdot \mathrm{kg}^{-1}\right)$ & $1.3 \pm 0.4 \mathrm{a}$ & $1.4 \pm 0.4 \mathrm{a}$ & $1.4 \pm 0.4 \mathrm{a}$ & $1.4 \pm 0.4 \mathrm{a}$ & $1.3 \pm 0.4 \mathrm{a}$ \\
\hline Zinc $\left(\mathrm{mg} \cdot \mathrm{kg}^{-1}\right)$ & $1.3 \pm 0.3 \mathrm{a}$ & $1.2 \pm 0.3 \mathrm{a}$ & $1.3 \pm 0.3 \mathrm{a}$ & $1.1 \pm 0.3 \mathrm{a}$ & $1.2 \pm 0.3 \mathrm{a}$ \\
\hline
\end{tabular}

${ }^{1} \mathrm{TO}$ to $\mathrm{T} 100$ indicates air-dried rough agave flowers at $0 \%$ (control), $25 \%, 50 \%, 75 \%$, and $100 \%$ of the roughage contained in the diet.

${ }^{2}$ Means with different lowercase letters within a row differ at $P<0.05$.

visitors of this plant: bats, honeybees, hummingbirds, bumblebees, and hawkmoths.

Finally, the feeding regime used in the present study could fit into a traditional goat production systems in the arid zones of northern Mexico. The primary source of revenues for goat producers in xeric landscapes of northern Mexico is milk yield; thus, weaning goats at 2 mo would increase yield of marketable milk because all milk destined to rear kids (weaning is not possible in this extensive management system) will be marketed. An additional important advantage of this feeding regime is that age at first kidding of young goats would occur at $1 \mathrm{yr}$ instead of $2 \mathrm{yr}$ of age as occurs under the traditional extensive systems.

\section{LITERATURE CITED}

Abebe, G., R. C. Merkel, G. Animut, T. Sahlu, and A. L. Goetsch. 2005. Effects of ammoniation of wheat straw and supplementation with soybean meal or broiler litter on feed intake and digestion in yearling Spanish goat wethers. Small Ruminant Research 51:37-46.

[AOAC] Association of Official Analytical Chemists. 1990. Official methods of analysis. Volume 2. 15th ed. Arlington, VA, USA: AOAC. 134 p.

Aregheore, E. M. 2006. Utilization of concentrate supplements containing varying levels of copra cake (Cocos nucifera) by growing goats fed a basal diet of napier grass (Pennisetum purpureum). Small Ruminant Research 64:87-93.

Azócar, P., H. Rojo, J. Mira, and H. Manterola. 1996. Inclusión de nummmularia (Atriplex nummularia Lindl.) y cladodios de tuna (Opuntia ficus-indica) en la dieta de cabras criollas en reemplazo de heno de alfalfa, I: efecto en el consumo, peso vivo y producción de leche. Avances en Producción Animal (Chile) 21:43-50.

Cabiddu, A., A. Branca, M. Decandia, A. Pes, P. M. Santucci, F. Masoero, and L. Calamari. 1999. Relationship between body condition score, metabolic profile, milk yield and milk composition in goats browsing a Mediterranean shrubland. Livestock Production Science 61:267-263.

Carlsson, J., and B. Pehron. 1994. The influence of the dietary balance between energy and protein on milk urea concentration: experimental trials assessed by two different protein evaluation systems. Acta Veterinaria Scandinavica 35:193-205.

Cerrillto, M. A., 0. 0. López, C. G. Nevárez, R. G. Ramírez, and R. A. S. Juárez. 2006. Nutrient content, intake and in vitro gas production of diets by Spanish goats browsing a thorn shrubland in North Mexico. Small Ruminant Research 66:76-84.

Comisión Nacional del Agua. 2002. Determinación de la disponibilidad de agua en el acuífero principal, estados de Durango y Coahuila. Gerencia de Aguas Subterráneas, Mexico: CONAGUA. 24 p.
Garcia-Salazar, J. A., E. Guzmán-Soria, and M. Fortis-Hernández. 2006. Water demand and distribution in the comarca lagunera, México. Agrociencia 40:269-276.

Getachew, G., P. H. Robinson, E. J. Depeters, and S. J. Taylor. 2004. Relationships between chemical composition, dry matter degradation and in vitro gas production of several ruminant feeds. Animal Feed Science and Technology 111:57-71.

Givens, D. I., A. R. Moss, and A. H. Adamson. 1992. The chemical composition and energy value of high temperature dried grass produced in England. Animal Feed Science and Technology 36:215-228.

Grigsby, K. N., C. W. Peters, M. S. Kerley, and J. A. Paterson. 1991. Digestibility of vegetative and mature tall fescue greenchop with or without alfalfa greenchop substitution. Journal of Animal Science 69:4602-4610.

Gustavsson, A. M., and K. Martinsson. 2004. Seasonal variation in biochemical composition of cell walls, digestibility, morphology, growth and phenology in timothy. European Journal of Agronomy 20:293-312.

HadDAD, S. G. 2000. Associative effects of supplementing barley straw diets with alfalfa hay on rumen environment and nutrient intake and digestibility for ewes. Animal Feed Science and Technology 87:163-171.

Hill, G. M., P. R. Utley, And G. L. Newton. 1986. Influence of dietary crude protein on peanut skin digestibility and utilization by feedlot steers. Journal of Animal Science 62:887-894.

Holechek, J. L., R. E. Estell, M. L. Galyean, and W. Richards. 1989. Chemical composition, in vitro digestibility and in vitro VFA concentrations of New Mexico native forages. Grass and Forage Science 44:101-105.

Hunt, C. W., J. A. Paterson, and J. E. Williams. 1985. Intake and digestibility of alfalfa-tall fescue combination diets fed to lambs. Journal of Animal Science 60:301-306.

KeENEY, M. 1955. Direct chromatographic determination $C_{1}-C_{6}$ fatty acids in rumen fluid. College Park, MD, USA: Maryland Agriculture Experimental Station, Miscellaneous Publication 238. 23 p.

Khazaal, K., M. T. Dentinho, J. M. Ribeiro, and E. R. Orskov. 1995. Prediction of apparent digestibility and voluntary feed intake of hays fed to sheep: comparison between using fibre component, in vitro digestibility or characteristics of gas production or nylon bag degradation. Animal Science 61:521-538.

LaLLo, C. H. 0. 1996. Feed intake and nitrogen utilization by growing goats fed byproduct based diets of different protein and energy levels. Small Ruminant Research 22:193-204.

Li, Y., S. D. Arnold, C. Kozel, and S. Forster-Cox. 2005. Water availability and usage on the New Mexico/Mexico border. Journal of Environmental Health 68:10-17.

Magdus, M., S. Fekete, L. V. Frenyó, O. Miskucza, And L. Kotz. 1988. Milk production and certain parameters of energy metabolism in dairy cows fed rations of varying energy and crude protein contents and fat. Acta Veterinaria Hungarica 36:43-59.

Martinez, C. J. 1994. Feeding value of two maguey species: Agave atrovirens Kart and Agave salmiana in southern Coahuila State [thesis]. Saltillo, Coahuila, Mexico: Universidad Autonoma Agraria Antonio Narro. 57 p. 
Mcmillan, Z., C. B. Scott, C. A. Taylor, JR., and J. E. Huston. 2002. Nutritional value and intake of prickly pear by goats. Journal of Range Management 55: 139-143.

Meissner, H. H. 1997. Recent research on forage utilization by ruminant livestock in South Africa. Animal Feed Science and Technology 69:103-119.

Menke, K. H., and H. Steingass. 1988. Estimation of the energetic feed value obtained from chemical analysis and in vitro gas production using rumen fluid. Animal Research Development 28:7-55.

Misra, A. K., A. S. Mishra, M. K. Tripathi, 0. H. Chaturvedi, S. Vaithiyanathan, R. Prasad, and R. C. Jakhmola. 2006. Intake, digestion and microbial protein synthesis in sheep on hay supplemented with prickly pear cactus [Opuntia ficus-indica (L.) Mill.] with or without groundnut meal. Small Ruminant Research 63:125-134

Moss, A. R., D. I. Givens, And R. H. Phipps. 1992. Digestibility and energy value of combinations of forage mixtures. Animal Feed Science and Technology 39: 151-172.

Nantoumé, H., T. D. A. Forbes, C. M. Hensarling, and S. Sieckenius. 2001. Nutritive value and palatability of guajillo (Acacia berlandieri) as a component of goat diets. Small Ruminant Research 40:139-148.

Negesse, T., M. Rodehutscord, and E. Pfeffer. 2001. The effect of dietary crude protein level on intake, growth, protein retention and utilization of growing male Saanen kids. Small Ruminant Research 39:243-251.

National Research Council. 2007. Nutrient requirements of small ruminants: sheep, goats, cervids and new world camelids. Washington, DC, USA: National Academy Press. $384 \mathrm{p}$.

ØRSKOV, E. R. 1982. Protein nutrition in ruminants. London, United Kingdom: Academic Press. 160 p.

Ramirez, R. G., L. A. Hauad, R. Foroughbakhch, and L. A. Pérez-López. 1997. Seasonal concentrations of in-vitro volatile fatty acids in leaves of 10 native shrubs of northeastern Mexico: Forest, Farm, and Community Tree Research Reports 2:4-7.
Ramirez, R., and J. L. Hernandez. 1997. Nutritional profile and leaf surface structure of some native shrubs consumed by small ruminants in semiarid regions of northeastern Mexico. Journal of Applied Animal Research 11:145-156.

Ramírez-Orduña, R., R. G. Ramírez-Lozano, M. V. Gómez-Meza, J. A. Armenta-Quintana, J. M. Ramírez-Orduña, R. Cepeda-Palacios, and J. M. Ávila-Sandoval. 2003. Seasonal dynamics of ruminal crude protein digestion of browse species from Baja California Sur, Mexico. Interciencia 28:408-414.

Richards, D. E., W. F. Brown, G. Ruegsegger, and D. B. Bates. 1994. Replacement value of tree legumes for concentrates in forage-based diets, I: replacement value of Gliricidia sepium for growing goats. Animal Feed Science and Technology 46:37-51.

SAS. 1990. SAS User's Guide: Statistics (Version 6.06). Cary, NC, USA: SAS Institute Inc. 1028 p.

Sheridan, R., A. V. Ferreira, and L. C. Hoffman. 2003. Production efficiency of South African Mutton Merino lambs and Boer goat kids receiving either a low or a high energy feedlot diet. Small Ruminant Research 50:75-82.

SiroHI, S. K., S. A. Karim, and A. K. Misra. 1997. Nutrient intake and utilisation in sheep fed with prickly pear cactus. Journal of Arid Environments 36:161-166.

Terrill, T. H., A. M. Rowman, G. B. Douglas, and T. N. Barry. 1992. Determination of extractable and bound condensed tannin concentrations in forage plants, protein concentrate meals and cereal grains. Journal of the Science of Food and Agriculture 58:321-329.

Van Soest, P. J., J. B. Robertson, and B. A. Lewis. 1991. Methods for dietary fiber, neutral detergent fiber and non-starch carbohydrates in relation to animal nutrition. Journal of Dairy Science 74:3583-3597.

WeIss, J. L., AND J. T. OverPeCK. 2005. Is the Sonoran Desert losing its cool? Global Change Biology 11:2065-2077.

Yerena, F., H. M. Ferreiro, R. Elloott, R. Godoy, and T. R. Preston. 1977. Digestibility of ramon (Brosimum alicastrum), leucaena leucocephala, buffel grass (Cenchus ciliare), sisal pulp and sisal bagasse (Agave fourcroydes). Tropical Animal Production 3:27-29. 